\title{
MICROBIAL CONTROL IN WHITE CACTUS PEAR WITH BIOPOLYMERIC COATING OF CHITOSAN, CANDELILLA WAX AND THYME ESSENTIAL OIL
}

\section{CONTROL MICROBIANO EN FRUTOS DE TUNA BLANCA CON RECUBRIMIENTO BIOPOLIMÉRICO DE QUITOSANO, CERA DE CANDELILLA Y ACEITE ESENCIAL DE TOMILLO}

\author{
Daniel J. Valle-Ortiz' ${ }^{1}$ Adalberto Gómez-Cruz ${ }^{1}$, \\ Alma D. Hernández-Fuentes ${ }^{2}$ and Salvador Valle-Guadarrama ${ }^{1}$ *
}

\author{
'Universidad Autónoma Chapingo, Departamento de Ingeniería Agroindustrial, Texcoco, Estado de México, México. ${ }^{2}$ Universidad Autónoma del \\ Estado de Hidalgo, Tulancingo, Hidalgo, México. \\ *Autor de correspondencia (svalleg@taurus.chapingo.mx)
}

\section{SUMMARY}

White cactus pear (Opuntia albicarpa L.) undergoes decay by pathogens in postharvest, which limits its shelf life. The objective of this study was to evaluate coatings based on chitosan (Q), candelilla (Euphorbia antisyphilitica Zucc.) wax (Cw) and thyme (Thymus vulgaris $\mathrm{L}$.) essential oil (Eo) to reduce microbial development on the cactus pear and increase shelf life. Emulsions based on Q, Eo, and Q+Eo were applied on freshly harvested cactus pear fruits, which were stored for 18 days at $22^{\circ} \mathrm{C}$. Treatments with $\mathrm{Q}$ also incorporated $\mathrm{Cw}$. Controls were uncoated fruits (Ct). Microbial inhibition was assessed through bacterial counting in culture plate, in addition to the appearance of the fruit on a visual scale 1 to 5 , where 1 corresponded to appalling and 5 to excellent. Fruits with the $Q+E o$ treatment had an appearance close to 4 at the end of the storage, followed by those with Q, Eo, and T, which obtained a score of 1 . The lowest weight loss occurred when $\mathrm{Cw}$ was used. With a coating of $\mathrm{Q}(2 \%)$, Eo (2000 ppm) and Cw (5\%) microbial growth was reduced by 98.4 $\%$, allowing a shelf life of at least 18 days at $22{ }^{\circ} \mathrm{C}$, with good appearance and low weight loss in fruits.

Index words: Opuntia albicarpa, fruit quality, postharvest, shelf life.

\section{RESUMEN}

La tuna blanca (Opuntia albicarpa L.) experimenta daños por patógenos en postcosecha, lo que limita su vida de anaquel. El objetivo de este trabajo fue evaluar recubrimientos basados en quitosano (Q), cera de candelilla (CC) (Euphorbia antisyphilitica Zucc.) y aceite esencial (Ae) de tomillo (Thymus vulgaris $\mathrm{L}$.) para reducir el desarrollo microbiano en tuna e incrementar la vida de anaquel. Se aplicaron emulsiones con $\mathrm{Q}, \mathrm{Ae}$ y $\mathrm{Q}+\mathrm{Ae}$ sobre frutos de tuna recién cosechados y se almacenaron por 18 días a $22^{\circ} \mathrm{C}$. Los tratamientos con Q también incorporaron Cc. Los testigos fueron frutos sin recubrir (T). Se evaluó inhibición microbiana mediante cuenta bacteriana en placa de cultivo, además de la apariencia del fruto en una escala visual de 1 a 5 , donde 1 corresponde a muy mala y 5 a excelente. Los frutos con el tratamiento $Q+A e$ tuvieron apariencia cercana a 4 al término del almacenamiento, seguidos de aquellos con $\mathrm{Q}$, Ae y $\mathrm{T}$, que obtuvieron calificación de 1. La menor pérdida de peso ocurrió cuando se usó Cc. Con recubrimiento de Q (2 \%), Ae (2000ppm) y Cc $(5 \%)$ se redujo el crecimiento microbiano en $98.4 \%$, permitiendo vida de anaquel de al menos 18 días a $22{ }^{\circ} \mathrm{C}$, con buena apariencia y baja pérdida de peso en frutos.

Palabras clave: Opuntia albicarpa, calidad de fruto, postcosecha, vida de anaquel.

\section{INTRODUCTION}

Cactus pear (Opuntia spp.) grows in arid and semi-arid regions of different countries, including Mexico, Chile, Argentina, Bolivia and Peru in America; Algeria, Ethiopia, Morocco, South Africa and Tunisia in Africa; Jordan, Lebanon, Syria and Israel in West Asia; Italy, Portugal and Spain in Europe, and in Australia (Ochoa and Barbera, 2017). The prickly pear, the fruit of the cactus, is a polyspermic, fleshy berry, with spiny texture on the outside (Feugang et al., 2006), of juicy consistency, rich in vitamins, minerals, proteins (De Wit et al., 2014) and rich in compounds with nutraceutical properties (Pinedo-Espinoza et al., 2017). The prickly pear, also named cactus pear, is a sweettasting fruit that is mostly consumed fresh, but it is susceptible to fungal and bacterial attack (Ammar et al., 2004; Granata et al., 2017; Swart, 2009). For this reason within a few days of handling under ambient conditions the fruit experiences decay (Ochoa-Velasco and GuerreroBeltrán, 2016) and rapid deterioration in terms of loss of appearance and quality, which reduces shelf life and limits commercialization. Refrigeration can be used as an alternative to extend postharvest life and to reduce losses (Ochoa-Velasco and Guerrero-Beltrán, 2016; RosasBenítez et al., 2016), but many producing regions do not have the required on infrastructure for this process; thus, other conservation options must be explored.

The microbial control of fruits and vegetables in postharvest can be carried out by using biopolymeric coatings (Usall et al., 2015) formulated with carbohydrates, proteins or lipids, and applied onto the surface of products to reduce water and solute losses, to limit gas exchange and to serve as a vehicle to incorporate additives (Chiralt et al., 2012). Chitosan, a compound obtained by deacetylation of chitin (Hamed et al., 2016), is a common ingredient of biopolymeric coatings (Kerch, 2015) that 
can reduce the decay of fruits through destabilization of microorganisms that cause diseases (Ayala, 2015). Another alternative to achieve microbial control is the use of plant extracts (Montes-de-Oca-Márquez et al., 2017). Essential oils, as that obtained from thyme (Thymus vulgaris), can inhibit distinct microbial species of bacterial (Teixeira et al., 2013) or fungal type (Correa-Pacheco et al., 2017). The antimicrobial effect of biopolymeric coatings can be improved by combining compounds that share this characteristic; thus, the antimicrobial properties of chitosan might be improved with the combined use of essential oils (Correa-Pacheco et al., 2017; Grande-Tovar et al., 2018). The application of biopolymeric coatings to control the microbial development that causes rot has not been evaluated in cactus pears, and the use of a strategy based on chitosan and an essential oil, either alone or in combination, could reduce postharvest losses at ambient temperature, which constitutes the most common handling condition. On the other hand, it is common to complement biopolymeric coatings with lipidic materials to reduce water loss by transpiration (Chiumarelli and Hubinger, 2014). In the present study, candelilla wax, a product obtained from Euphorbia antisyphilitica Zucc., was used together with chitosan, because it is generally recognized as safe (FDA, 2003) and because it forms films with suitable properties as a water-vapor barrier (LozanoGrande et al., 2016). The present study was conducted with the objective of evaluating the use of biopolymeric coatings based on chitosan, candelilla wax and thyme essential oil to reduce the microbial development over white cactus pears at postharvest to increase shelf life.

\section{MATERIALS AND METHODS}

\section{Plant material}

White cactus pears (Opuntia albicarpa) of $156.1 \pm 28.1 \mathrm{~g}$, free of damage, were used. Harvest was carried out in San Martín de las Pirámides, Mexico (19 44' 15" N, $98^{\circ} 49^{\prime} 35^{\prime \prime}$ W, 2311 masl) at consumption maturity, with a full floral receptacle cavity (Potgieter and D'Aquino, 2017). Spines were removed from the peel at the place of production with rotating brushes placed in a continuous-flow band.

\section{Antimicrobial effect of mixtures of chitosan and thyme essential oil}

\section{Inoculum preparation}

Fifteen white cactus pears were stored at $25^{\circ} \mathrm{C}$ and 63 $\%$ relative humidity until rot development was observed in more than $50 \%$ of the epicarp, which occurred after 18 days by showing tissue necrosis, absence of mycelial growth and bad smell. Preparations were set from smears of the necrotized tissue for observation at the optical microscope. In addition, samples of $10 \mathrm{~g}$ of the epicarp of five fruit were stirred for $3 \mathrm{~min}$ in $90 \mathrm{~mL}$ of sterile water with a magnetic element; sequential samplings were performed to obtain $10^{-3}$ dilutions, which constituted stock solutions.

\section{Experimental organization}

Three experiments were conducted in sequence to evaluate the antimicrobial effect of chitosan ( $Q$ ) and thyme essential oil (Eo) by adding them to nutritive agar culture media (Bioxon, Becton Dickinson de México, S.A. de C. V.). In the first one, the presence of Eo was evaluated at concentrations of 100, 200, 500, 1000 and 2000 ppm. In the second one, Q concentrations of 0.5, 1.0, 1.5 and 2.0 $\%$ were evaluated. In the third experiment, the combination of Eo at concentrations of 100, 200, 500, 1000 and 2000 ppm, with $\mathrm{Q}$ at $2 \%$ concentration $(\mathrm{Q}+\mathrm{Eo})$ was evaluated. In the three cases, a culture medium without antimicrobial agent was used as a control treatment (Ct) and all routines were performed in triplicate. The thyme essential oil was provided by Droguería Cosmopolita S.A. de C.V. (Mexico) and was used in mixture with Tween 80 (Hycel de México S.A. de C. V.) as emulsifier, in a proportion of $20 \%$ in relation to the amount of oil. Chitosan had molecular weight of 190-310 kDa, degree of deacetylation of 75-85\% and was provided by Sigma-Aldrich Química de México S.A. de C.V. (Catalog 448877). The culture medium was cooled to 40$45{ }^{\circ} \mathrm{C}$ before adding Eo when this component was used within the formulation. Homogenization was performed with an Ultra Turrax T25 device (IKA Labortechnik, Staufen, Germany) at $3580 \times \mathrm{g}(16,000 \mathrm{rpm})$ for $15 \mathrm{~min}$. Aliquots of $0.1 \mathrm{~mL}$ of the stock solutions were poured and distributed onto the surface of the culture media with a sterile glass rod. The units were incubated at $35^{\circ} \mathrm{C}$ for $48 \mathrm{~h}$ and the microbial count was made in colony forming units per gram $\left(\mathrm{CFU} \mathrm{g^{-1 }}\right)$ on the plates.

\section{Data analysis}

The three experiments of this phase were analyzed using a completely randomized design. Microbial count data were subjected to analysis of variance and treatments means comparison tests (Tukey, $P \leq 0.05$ ).

\section{Application of biopolymeric coatings on fruit}

\section{Experimental organization}

Four batches of 60 fruits were formed and identified as $\mathrm{Ct}, \mathrm{Eo}, \mathrm{Q}$, and $\mathrm{Q}+\mathrm{Eo}$, respectively. Group Ct constituted the control and corresponded to fruits without any treatment. The Eo group was treated with an emulsion of thyme essential oil (Eo) at 2000 ppm concentration. Group Q was 
treated with an emulsion containing $2 \%$ chitosan and $5 \%$ candelilla wax (CW). Fruits of the $\mathrm{Q}+$ Eo group were coated with an emulsion containing $2 \%$ chitosan, $5 \%$ candelilla wax, and 2000 ppm essential oil. The coatings application was performed with a brush, individually, with equal volumes of $2.0 \mathrm{~mL}$ applied on each fruit. Batches were placed into a chamber at $22{ }^{\circ} \mathrm{C}$ and $65 \%$ relative humidity. This temperature was representative of the normal handling of fruits in producing areas, where there is no refrigeration infrastructure. On days 1, 3, 6, 9, 12, 15 and 18 , after the experiment installation, nine fruits were sampled from each batch to form three experimental units of three fruits each, which were submitted to evaluation of weight loss, appearance, epicarp color and microbial count on epicarp.

\section{Response variables}

Fruit of each experimental unit were weighed with a balance with accuracy of $0.1 \mathrm{~g}$ (Ohaus, Parsippany-Troy Hills, New Jersey, USA); weight loss was evaluated in percentage in relation to the initial storage condition. The appearance was evaluated with a categorical scale of five points: 1, very bad; 2 , bad; 3 , regular; 4 , good; 5 , excellent, with the collaboration of an untrained panel of five persons. Color was evaluated with a Hunter Lab colorimeter (Mini Scan XE Plus 45/0-L, Reston, VA, USA) and was expressed as lightness $(L *)$, hue angle $(H *)$, and chroma $(C *)$ (Carvajal et al., 2011). The microbial count was evaluated as CFU per $\mathrm{g}$ of epicarp (CFU g $\left.{ }^{-1}\right)$. To do this, $10 \mathrm{~g}$ of epicarp from the equatorial region of the fruit were placed into $90 \mathrm{~mL}$ of sterile distilled water and agitation was applied for 15 s. Dilutions were made to obtain $10^{-3}$ stock solutions. The inoculation was done by surface extension on nutritive agar plates, which were incubated at $35^{\circ} \mathrm{C}$ for $48 \mathrm{~h}$.

\section{Data analysis}

This phase was conducted under a completely randomized design, where treatments ( $\mathrm{Ct}$, Eo, $\mathrm{Q}$ and $\mathrm{Q}+\mathrm{Eo}$ ) were the variation source. An analysis of variance and tests of treatments means comparison (Tukey, $P \leq 0.05$ ) were performed. In addition, the significance of changes along time within each treatment was evaluated.

\section{RESULTS AND DISCUSSION}

\section{Antimicrobial effect of thyme essential oil and chitosan}

The microscopic observation of the inoculum obtained from rotting tissue revealed abundant bacterial development. Swart (2009) indicated that rot can manifest with the presence of fungi, yeasts, and bacteria, and has similar characteristics to the cladode contamination. Given the abundant presence of bacillary bacteria, the evaluations focused on this type of microorganism. The inoculation of culture media with Eo at concentrations of 100 and 200 ppm did not cause inhibition of bacterial growth $(P>0.05)$ and the microorganisms developed on the surface of the medium, which suggested that they were facultative aerobic bacilli (Madigan et al., 2009). The information on the type of bacteria associated with rot in cactus pear is scarce. The studies of Alcorn et al. (1991) and Varvaro et al. (1993) suggested that it could be a species of the genus Erwinia belonging to the filum of proteobacteria, which are Gram negative (Madigan et al., 2009). With concentrations of 500 and 1000 ppm, the CFU g gere reduced considerably (43.3 and $56.73 \%$, respectively), but without effect in relation to the control $(C t)(P>0.05)$.

A significant reduction (65.9\%) was obtained in relation to $\mathrm{Ct}(\mathrm{P} \leq 0.05)$ only with $2000 \mathrm{ppm}$ of Eo, but with no difference with respect to the $1000 \mathrm{ppm}$ treatment $(P>0.05)$ (Table 1). Teixeira et al. (2013) reported that the main components of thyme essential oil are monoterpenes thymol, carvacrol, and p-cymene, and can inhibit bacterial species such as Brochothrix thermosphacta, Escherichia coli, Listeria innocua, Listeria monocytogenes, Pseudomonas putida, Salmonella typhimurium and Shewanella putrefaciens at concentrations between 60 and 1000 ppm; however, in the present study it was observed that $1000 \mathrm{ppm}$ may not be sufficient to inhibit the causative microorganisms of rot in cactus pear, so it was considered appropriate to test at 2000 ppm. When chitosan ( $Q$ ) was used, even though a inhibitory tendency was observed with increased concentration, no significant difference was found between treatments $(P>0.05)$, nor in relation to the control (Table 1), which suggests high variability in results. Ayala (2015) explained that the effect of $Q$ is due to the presence of an amino group positively charged at $\mathrm{pH}$ below 6.3, which interacts with negative charges of the cell wall of microorganisms, which in turn induces breakdown of the structure and loss of protein compounds. Likewise, the outer membrane of Gram-negative bacteria contains cations that stabilize with negative charge of phosphate and carboxyl groups, and the interaction of chitosan with those cations causes a destabilization phenomenon.

The 100 and 200 ppm treatments of Eo combined with chitosan reduced microbial growth by 31.25 and 32.07 $\%$, respectively, compared to $\mathrm{Ct}$, but without significant difference $(P>0.05)$ (Table 1$)$. As Eo increased in the mixture with $Q$, greater inhibition was obtained than when the compounds were used separately. With concentrations of 1000 and $2000 \mathrm{ppm}$ of Eo the microbial development was practically inhibited (93.0 and $98.4 \%$ lower than $\mathrm{Ct}$, respectively; $\mathrm{P} \leq 0.05$ ), which suggests a synergistic 
effect between components. On this regard, it has been reported that the antimicrobial potential of chitosan can be increased through the combination with essential oils (Correa-Pacheco et al., 2017; Grande-Tovar et al., 2018); Mayachiew et al. (2010) pointed out that chitosan can interact through hydrogen bonds with terpenes of essential oils, affecting positively the antimicrobial activity of the mixtures.

\section{Postharvest fruit behavior}

\section{Appearance}

The best appearance (value equal to 5) corresponded to fruits evaluated at the time of harvest, but there was visual deterioration during storage (Figure 1A). At the end, the highest levels of rot occurred in uncoated fruits $(\mathrm{Ct})$ and the lowest ones in material treated with chitosan and essential oil. As a consequence, the treatment $\mathrm{Q}+\mathrm{Eo}$ maintained appearance with values near to the good score (3.7), followed by Q (3.3), then by Eo (2.3) and finally by Ct (1.0) (Figure 2), with a significant difference between all of them $(P \leq 0.05)$ (Figure 1A).

\section{Microbial load}

The highest bacterial count was found in $\mathrm{Ct}(\mathrm{P} \leq 0.05)$, then in Eo, followed by $\mathrm{Q}$, and the lowest one was found in fruits of the $\mathrm{Q}+$ Eo treatment (Figure 1B). The Eo and Q treatments caused similar outcome during 12 days of storage, but in the next six days the microbial load in Eo increased in relation to $Q(P \leq 0.05)$, which could be a result of loss of essential oil due to volatilization. This did not occur when candelilla wax (CW) was used, perhaps because of the affinity of this with oil, which favored its retention within the coating (Figure 1B). Studies on cactus diseases have focused mainly on cladodes, while studies on fruits are scarce (Swart, 2009). Although the initial analysis of the inoculum guided the evaluation of microbial activity as a bacterial count, the presence of fungal species has also been reported, particularly from genera Alternaria, Botryodiplodia and Fusarium (Ammar et al., 2004; Granata et al., 2017; Swart, 2009). This suggests that characterization of the rotting species in the region of study should be deepened. Although the reports of Alcorn et al. (1991), Granata et al. (2017) and Varvaro et al. (1993) have suggested the presence of bacteria of the Erwinia genus, the information corresponds to regions of Italy and Argentina. In Mexico there are no reports focused on the identification of bacteria causing rot in cactus pear; in this sense, Ammar et al. (2004) indicated that the microorganism can vary between regions.

\section{Attributes of color}

The initial hue angle $(\mathrm{H} *)$ varied between 106 and $111^{\circ}$ (Figure 1D). The values of 0 or $360^{\circ}, 90,180$, and $270^{\circ}$ correspond to red, yellow, green and blue, respectively (Carvajal et al., 2011). Thus, the tonality was yellowish green in epicarp, similar to that reported by Cefola et al. (2014), who qualified this as a typical characteristic of the white cactus pear at the time of harvest. The hue angle varied between 2 and $6^{\circ}$ during storage and despite the differences between treatments $(P \leq 0.05)$ the initial contrasts were maintained. Lightness $(L *)$ increased during storage, which was also reported by Meraz-Maldonado et al. (2012). The highest $L *$ corresponded to $C t$, where this attribute ranged from 53.65 to $57.32 \%$ (Figure 1E). The presence of essential oil caused a decrease in $L *$ and the Eo and $Q+$ Eo treatments caused a lesser value of $L *$ than in

Table 1. Comparison of microbial load (ML) means allowed by culture media with different concentration of antimicrobial agent.

\begin{tabular}{lccccc}
\hline \multicolumn{2}{c}{ Essential oil (Eo) } & \multicolumn{2}{c}{ Chitosan (Q) } & \multicolumn{2}{c}{$\mathrm{Q}(2 \%)+$ Eo } \\
\hline $\begin{array}{l}\text { Concentration } \\
(\mathrm{ppm})\end{array}$ & $\begin{array}{c}\mathrm{ML} \\
\left(\mathrm{CFU} \times 10^{3} \mathrm{~g}^{-1}\right)\end{array}$ & Concentration (\%) & $\begin{array}{c}\mathrm{ML} \\
\left(\mathrm{CFU}^{+} \times 10^{3} \mathrm{~g}^{-1}\right)\end{array}$ & $\begin{array}{c}\text { Concentration } \\
\text { of Eo }(\mathrm{ppm})\end{array}$ & $\begin{array}{c}\mathrm{ML} \\
\left(\mathrm{CFU}^{+} \times 10^{3} \mathrm{~g}^{-1}\right)\end{array}$ \\
\hline Control (0) & $208 \mathrm{abc}$ & Control (0) & $223 \mathrm{a}$ & Control (0) & $211 \mathrm{a}$ \\
100 & $281 \mathrm{a}$ & 0.5 & $200 \mathrm{a}$ & 100 & $154 \mathrm{ab}$ \\
200 & $239 \mathrm{ab}$ & 1.0 & $157 \mathrm{a}$ & 200 & $143 \mathrm{ab}$ \\
500 & $118 \mathrm{bcd}$ & 1.5 & $137 \mathrm{a}$ & 500 & $93 \mathrm{bc}$ \\
1000 & $90 \mathrm{~cd}$ & 2.0 & $134 \mathrm{a}$ & 1000 & $14 \mathrm{~cd}$ \\
2000 & $71 \mathrm{~d}$ & & & 2000 & $3 \mathrm{~d}$ \\
$\mathrm{HSD}^{++}$ & 129 & $\mathrm{HSD}$ & 95 & $\mathrm{HSD}$ & 111 \\
$\mathrm{CV}^{+1}$ & 28.3 & $\mathrm{CV}$ & 16.0 & $\mathrm{CV}$ & 29.1 \\
\hline
\end{tabular}

${ }^{+} \mathrm{CFU}$ : colony forming units, ${ }^{++} \mathrm{HSD}$ : Honest significant difference (Tukey, $\left.\mathrm{P} \leq 0.05\right), \mathrm{CV}$ : coefficient of variation. Means with equal letters within columns are not statistically different. Chitosan-based treatments were incorporated with $5 \%$ of candelilla wax. 

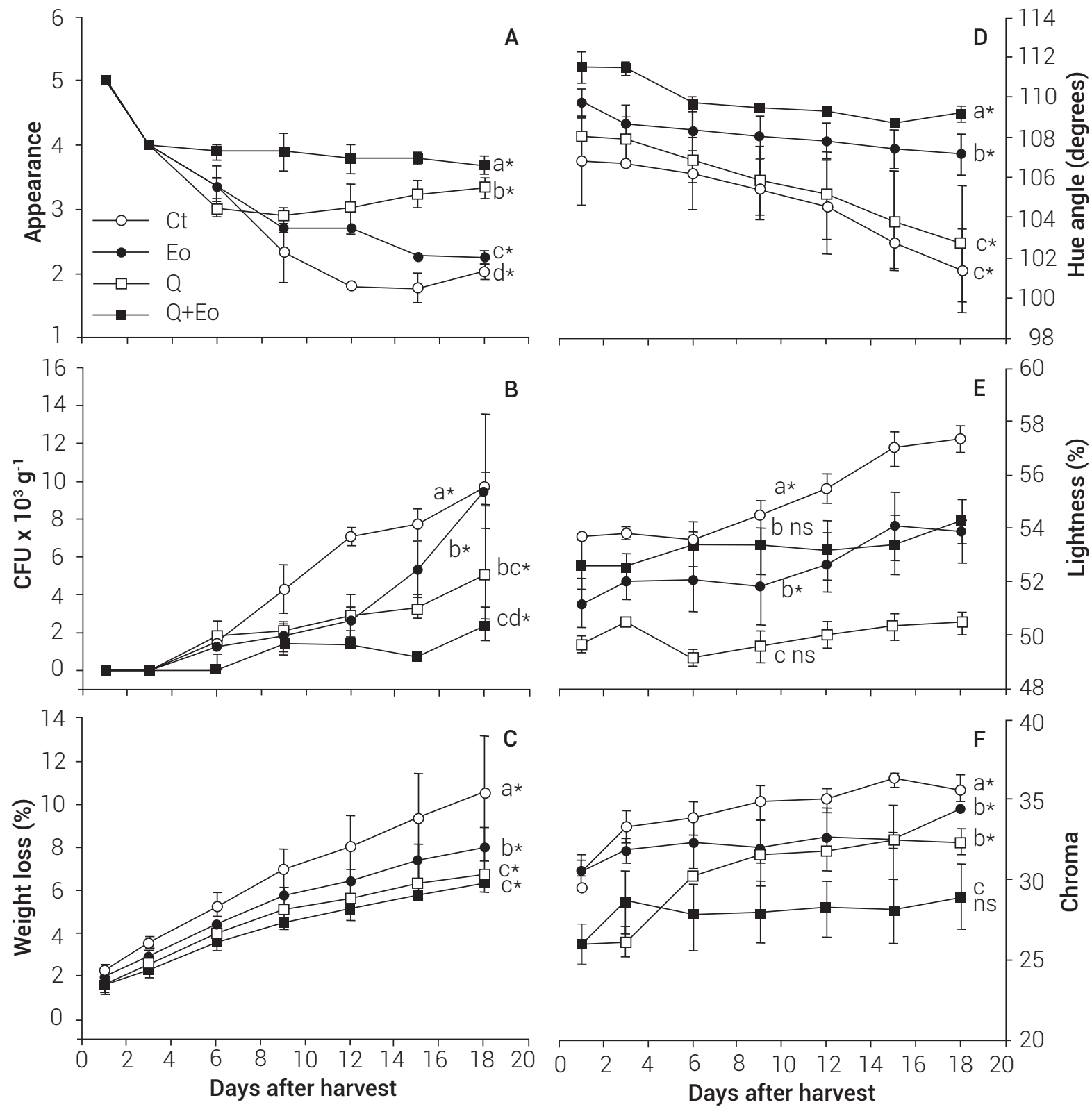

Figure 1. Variation of appearance (A), microbial count in colony forming units (CFU) per gram (B), weight loss (C), hue angle (D), lightness $(E)$, and chroma in epicarp $(F)$, of white cactus pears during a storage of 18 days at $22^{\circ} \mathrm{C}$. Equal letters indicate non-significant difference between treatments inside each box. The annotations * and ns indicate significant and non-significant change respectively, between the beginning and the end of storage (Tukey, $P \leq 0.05$ ). Vertical bars at each point represent the standard deviation of the average of three repetitions $(n=3)$. Ct is the control treatment; Eo, $Q$, and $\mathrm{Q}+\mathrm{Eo}$ are treatments with thyme essential oil, chitosan and a mixture of chitosan and essential oil, respectively. Chitosanbased treatments were incorporated with $5 \%$ candelilla wax. 


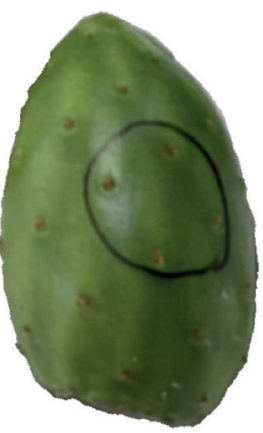

Initial condition

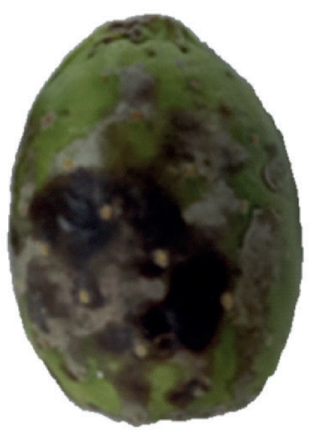

$\mathrm{Ct}$

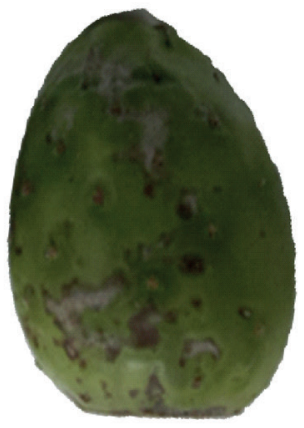

Eo

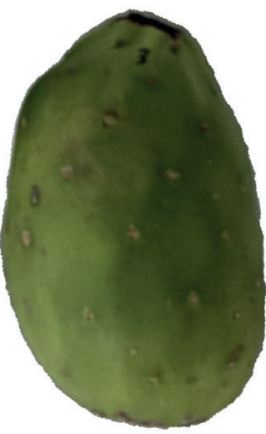

Q

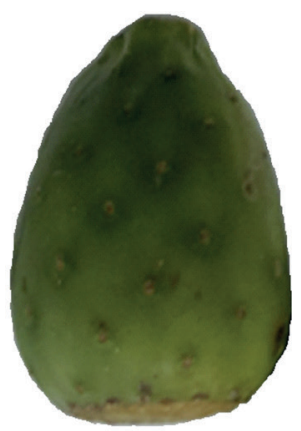

$Q+$ Eo

Figure 2. Appearance of white cactus pears at the initial condition $(t=0)$ and after 18 days of storage at $22^{\circ} \mathrm{C}$. Ct: control treatment, Eo: treatment with thyme essential oil $(2000 \mathrm{ppm}), \mathrm{Q}$ : treatment with chitosan $(2 \%), \mathrm{Q}+\mathrm{Eo}$ : treatment with chitosan ( $2 \%)$ and thyme essential oil $(2000 \mathrm{ppm})$. The $Q$ and $Q+$ Eo treatments also included candelilla wax $(5 \%)$.

Ct $(P \leq 0.05)$, without difference between them $(P>0.5)$, and with average changes from 51.9 to $54.0 \%$. The $Q$ treatment presented the lowest values, with an opaque appearance, which corresponded to L* from 49.7 to $50.8 \%$. Lightness ranged from zero (black) to $100 \%$ (white) (Carvajal et al., 2011); thus, with a coating, fruits may reflect less light, which could lead to an increment in temperature during open field operations. Chroma $\left(C^{*}\right)$ caused the formation of two groups, the first one with $\mathrm{Ct}$ and Eo with average values of 30.60, and the second one with $\mathrm{Q}$ and $\mathrm{Q}+$ Eo with average values of 26.96. This suggested that chitosan and candelilla wax reduced color purity (Carvajal et al., 2011). Treatments that contained essential oil showed an increase in $C *$ during storage, contrary to fruits coated with a chitosan and candelilla wax, where chroma remained constant (Figure 1F).

\section{Weight loss}

All the fruits lost weight (Figure 1D), which is mainly attributed to transpiration (Hübert and Lang, 2012). In the cases of $\mathrm{Q}$ and $\mathrm{Q}+\mathrm{Eo}$, candelilla wax (Cw) was added to reduce the loss and these treatments attained the lowest values $(P \leq 0.05)$. It has been shown that the addition of Cw causes decrease in weight loss (Lozano-Grande et al., 2016).

\section{Shelf life}

The appearance can provide an appraisal of shelf life (Ochoa-Velasco and Guerrero-Beltrán, 2016). Fruits of Ct, Eo and $Q$ had regular appearance (values near 3 ) after six days of storage, which may be the limit of postharvest life. The Q+Eo treatment caused good appearance (values near 4; Figure 1A) and fruits of this treatment had low microbial load and the smallest weight loss. With this, the best alternative was the use of a coating with chitosan 2 $\%$, thyme essential oil at concentration of $2000 \mathrm{ppm}$ and candelilla wax at concentration of $5 \%$, which allowed shelf life of at least 18 days with good appearance.

\section{CONCLUSIONS}

The use of biopolymeric coatings based on chitosan and thyme essential oil allowed an extended shelf life of white cactus pears handled under ambient conditions for up to 18 days. Chitosan and essential oil reduced microbial development, but their combination improved the potential to limit the growth of facultative aerobic bacteria. The use of candelilla wax favored the reduction of weight loss by transpiration.

\section{BIBLIOGRAPHY}

Alcorn S. M., T. V. Orum, A. G. Steigerwalt, J. L. M. Foster, J. C. Fogleman and D. J. Brenner (1991) Taxonomy and pathogenicity of Erwinia cacticida sp. nov. International Journal of Systematic Bacteriology 41:197212, https://doi.org/10.1099/00207713-41-2-197

Ammar M. I., A. M. Shltout and M. A. Kamhawy (2004) Cladode and fruit rots of prickly pear (Opuntia ficus-indica L. Mill.) in Egypt. Egyptian Journal of Phytopathology 32:119-128.

Ayala V. G. (2015) Efecto antimicrobiano del quitosano: una revisión de la literatura. Scientia Agroalimentaria 2:32-38.

Carvajal H. J. J., I. D. Aristizábal T., C. E. Oliveros T. y J. W. Mejía M. (2011) Colorimetría del fruto de café (Coffea arabica L.) durante su desarrollo y maduración. Revista Facultad Nacional de Agronomía Medellín 64:6229-6240.

Cefola M., M. Renna and B. Pace (2014) Marketability of ready-toeat cactus pear as affected by temperature and modified atmosphere. Journal of Food Science and Technology 51:2533, https://doi.org/10.1007/s13197-011-0470-5

Chiralt A., M. J. Fabra y L. Sánchez-González (2012) Propiedades de las películas comestibles. In: Películas y Recubrimientos Comestibles. Propiedades y Aplicaciones en Alimentos. G. I. Olivas O., G. A. González-Aguilar, O. Martín-Belloso y R. SolivaFortuny (eds.). Clave Editorial. México, D. F. pp:21-58. 
Chiumarelli M. and M. D. Hubinger (2014) Evaluation of edible films and coatings formulated with cassava starch, glycerol, carnauba wax and stearic acid. Food Hydrocolloids 38:2027, https://doi.org/10.1016/j.foodhyd.2013.11.013

Correa-Pacheco Z. N., S. Bautista-Baños, M. A. Valle-Marquina and M. Hernández-López (2017) The effect of nanostructured chitosan and chitosan-thyme essential oil coatings on Colletotrichum gloeosporioides growth in vitro and on $\mathrm{cv}$ Hass avocado and fruit quality. Journal of Phytopathology 165:297-305, https://doi.org/10.1111/jph.12562

De Wit M., C. Bothma, P. Swart, M. Frey and A. Hugo (2014) Thermal treatment, jelly processing and sensory evaluation of cactus pear fruit juice. Journal of the Professional Association for Cactus Development 16:1-14

FDA, Food and Drug Administration (2003) Code of Federal Regulations Title 21, Food and Drugs, CFR184. U. S. Department of Health and Human Services, Food and Drug Administration. Washington D. C. $559 \mathrm{p}$

Feugang J. M., P. Konarski, D. Zou, F. C. Stintzing and C. Zou (2006) Nutritional and medicinal use of cactus pear (Opuntia spp.) cladodes and fruits. Frontiers in Bioscience 11:2574-2589, https://doi.org/10.2741/1992

Granata G., R. Faedda and M. J. Ochoa (2017) Diseases of cactus pear. In: Crop Ecology, Cultivation and Uses of Cactus Pear. P Inglese, C. Mondragon, A. Nefzaoui and C. Sáenz (eds.). Food and Agriculture Organization of the United Nations and The International Center for Agricultural Research in the Dry Areas. Rome, Italy. pp:115-124

Grande-Tovar C. D., C. Chaves-Lopez, A. Serio, C. Rossi and A. Paparella (2018) Chitosan coatings enriched with essential oils: effects on fungi involved in fruit decay and mechanisms of action. Trends in Food Science and Technology 78:61-71, https://doi.org/10.1016/j.tifs.2018.05.019

Hamed I., F. Özogul and J. M. Regenstein (2016) Industrial applications of crustacean by-products (chitin, chitosan, and chitooligosaccharides): review. Trends in Food Science and Technology 48:40-50, https://doi.org/10.1016/j.tifs.2015.11.007

Hübert T. and C. Lang (2012) Artificial fruit: postharvest online monitoring of agricultural food by measuring humidity and temperature. International Journal of Thermophysics 33:1606-1615, https:// doi.org/10.1007/s10765-011-1101-0

Kerch G. (2015) Chitosan films and coatings prevent losses of fresh fruit nutritional quality: a review. Trends in Food Science and Technology 46:159-166, https://doi.org/10.1016/j.tifs.2015.10.010

Lozano-Grande M. A., S. Valle-Guadarrama, E. Aguirre-Mandujano, C. S. 0. Lobato-Calleros and F. Huelitl-Palacios (2016) Films based on hawthorn (Crataegus spp.) fruit pectin and candelilla wax emulsions: characterization and application on Pleurotus ostreatus. Agrociencia 50:849-866

Madigan M. T., J. M. Martinko, P. V. Dunlap and D. P. Clark (2009) Brock. Biología de los Microorganismos. Pearson Education. México, D. F. 1259 p.

Mayachiew P., S. Devahastin, B. M. Mackey and K. Niranjan (2010) Effects of drying methods and conditions on antimicrobial activity of edible chitosan films enriched with galangal extract. Food Research International 43:125-132, https://doi.org/10.1016/j.foodres.2009.09.006

Meraz-Maldonado N., S. Valle-Guadarrama, J. Hernández-Morales, S. AnayaRosales, J. C. Rodríguez-Maciel and G. Leyva-Ruelas (2012) Quality of three sizes of prickly pear cactus stems (Opuntia ficusindica L. "ATLIXCO"). African Journal of Agricultural Research 7:4512-4520.

Montes-de-Oca-Márquez C., C. T. Hernández-Delgado, J. Orozco-Martínez, A. M. García-Bores, J. G. Ávila-Acevedo, M. T. Ortiz-Melo, I. PeñalosaCastro, G. López-Moreno y R. Serrano-Parrales (2017) Actividad antibacteriana y antifúngica de Dalea carthagenensis (Jacq.) J F. Macbr. Revista Fitotecnia Mexicana 40:161-168.

Ochoa M. J. and G. Barbera (2017) History, economic and agro-ecological importance. In: Crop Ecology, Cultivation and Uses of Cactus Pear. P. Inglese, C. Mondragon, A. Nefzaoui and C. Sáenz (eds.) Food and Agriculture Organization of the United Nations and The International Center for Agricultural Research in the Dry Areas. Rome, Italy. pp:1-12

Ochoa-Velasco C. E. and J. A. Guerrero-Beltrán (2016) The effects of modified atmospheres on prickly pear (Opuntia albicarpa) stored at different temperatures. Postharvest Biology and Technology 111:314-321, https://doi.org/10.1016/j.postharvbio.2015.09.028

Pinedo-Espinoza J. M., C. L. Aguirre-Mancilla, R. Jiménez-Alvarado, J. C. Raya-Pérez, G. Iturriaga, J. G. Ramírez-Pimentel and A. D. Hernández Fuentes (2017) Bioactive compounds and antioxidant activity evolution during the ripening process of 12 Opuntia spp. fruit accessions. Emirates Journal of Food and Agriculture 29:138148, https://doi.org/10.9755/ejfa.2016-09-1324

Potgieter J. and S. D'Aquino (2017) Fruit production and post-harvest management. In: Crop Ecology, Cultivation and Uses of Cactus Pear. P. Inglese, C. Mondragon, A. Nefzaoui and C. Sáenz (eds.) Food and Agriculture Organization of the United Nations and The International Center for Agricultural Research in the Dry Areas. Rome, Italy. pp: 51-72

Rosas-Benítez A., L. Trujillo-Cárdenas, S. Valle-Guadarrama, Y. Salinas-Moreno and L. García-Cruz (2016) Quality attributes of pitaya (Stenocereus pruinosus) fruit handled in postharvest with and without thorns under refrigerated storage. Revista Chapingo Serie Horticultura 22:191-207, https://doi.org/10.5154/r.rchsh.2016.04.011

Swart W. J. (2009) Strategies for the management of cactus pear diseases: a global perspective. Acta Horticulturae 811:207-216 https://doi.org/10.17660/ActaHortic.2009.811.25

Teixeira B., A. Marques, C. Ramos, N. R. Neng, J. M. F. Nogueira, J. A Saraiva and M. L. Nunes (2013) Chemical composition and antibacterial and antioxidant properties of commercial essential oils. Industrial Crops and Products 43:587-595 https://doi.org/10.1016/j.indcrop.2012.07.069

Usall J., C. Casals, M. Sisquella, L. Palou and A. De Cal (2015) Alternative technologies to control postharvest diseases of stone fruits. Stewart Postharvest Review 11:1-6, https://doi.org/10.2212/spr.2015.4.2

Varvaro L., G. Granata and G. M. Balestra(1993) Severe Erwinia-caused damage on Opuntia ficus-indica in Italy. Journal of Phytopathology 138:325-330, https://doi.org/10.1111/j.1439-0434.1993.tb01392.x 
